Paolo Montagna · Sergio Silenzi ·

Saverio Devoti · Claudio Mazzoli ·

Malcolm McCulloch · Giovanni Scicchitano ·

Marco Taviani

\title{
Climate Reconstructions and Monitoring in the Mediterranean Sea: A Review on Some Recently Discovered High-Resolution Marine Archives
}

Received: 30 June 2007 / Accepted: 18 April 2008 - (C) Springer-Verlag 2008

\begin{abstract}
Palaeoclimate records are important tools for understanding climate modifications and contextualizing recent anthropogenic perturbations in climate change relative to natural variability in the Earthclimate system.
\end{abstract}

P. Montagna $(\varangle)$

ICRAM, Istituto Centrale per la Ricerca scientifica e tecnologica Applicata al Mare, Via di Casalotti 300, 00166, Rome (Italy). ISMAR, Instituto di Scienze Marine, CNR, Via P. Gobetti 101, 40129 Bologna (Italy)

Tel.: +39 0661570532,Fax: +39 0661561906,E-mail: p.montagna@icram.org

S. Silenzi

ICRAM, Istituto Centrale per la Ricerca scientifica e tecnologica Applicata al Mare, Via di Casalotti 300, 00166, Rome (Italy)

Tel.: +39 0661570436, Fax: +39 0661561906, E-mail: s.silenzi@icram.org

S. Devoti

ICRAM, Istituto Centrale per la Ricerca scientifica e tecnologica Applicata al Mare, Via di Casalotti 300, 00166, Rome (Italy)

Tel.: +39 0661570436, Fax: +39 0661561906, E-mail: s.devoti@icram.org

C. Mazzoli

Dipartimento di Geoscienze, Università di Padova, Via Giotto 1, 35121 Padova (Italy)

Tel.: +39 0498272017,Fax:+39 0498272070,E-mail: claudio.mazzoli@unipd.it

\section{McCulloch}

Research School of Earth Sciences, Australian National University, Mills Road, Canberra, ACT 0200, Australia

Tel.: 0061 261259969; Fax: 0061-261250738,E-mail: Malcolm.McCulloch@anu.edu.au

G. Scicchitano

Dipartimento di Scienze Geologiche, Università di Catania, Corso Italia, 5595129 Catania (Italy)

Tel.: +39-0957195728, Fax: +39-0957195728,E-mail: g.scicchitano@unict.it

M. Taviani

Istituto di Scienze Marine (ISMAR), CNR, Via P. Gobetti 101, 40129 Bologna (Italy)

Tel.: +39-0516398874; Fax: +39-0516398939, E-mail: marco.taviani@bo.ismar.cnr.it 
Moreover, time-series proxy records of the main physical and chemical parameters in marine and continental environments are increasingly used for testing climate models in order to ascertain the reliability of projections for future scenarios in our greenhouse modified Earth.

In order to account for the limited number of continuous instrumental measurements of climatic variables in the past, such as sea surface temperature (SST), salinity (SSS), sea-level fluctuations and water chemistry, a complementary approach is the examination of geochemical tracers (i.e. trace elements and stable isotopes) in well-dated natural marine archives.

Recently, the Mediterranean Sea has been the focus of a number of studies where new high resolution climate archives have been investigated utilizing proxies for sea surface temperature, salinity, marine chemistry, and ocean circulation, different to those available for tropical regions. In particular, vermetids (Dendropoma petraeum), non-tropical zooxanthellate corals (Cladocora caespitosa) and cold-water corals (Desmophyllum dianthus, Lophelia pertusa and Madrepora oculata) have been studied by conventional and advanced analytical techniques (e.g., laser ablation ICP-MS, MC-ICP-MS, synchrotron X-ray fluorescence) and have been successfully used as high-resolution palaeoenvironmental proxies. Vermetid reefs have the potential to yield valuable information on past sea-level changes and SST, through the combination of stable isotopes and radiocarbon dating. The trace element concentration, in combination with U-series and radiocarbon dating, of the skeletal aragonite of the Mediterranean zooxanthellate coral Cladocora caespitosa, and of the coldwater corals Desmophyllum dianthus and Lophelia pertusa, has been successfully demonstrated to be a valid high-resolution SST archive, and a seawater chemistry and ocean circulation proxy, respectively. Here we present a review of our research over the last few years, aiming for the establishment of new natural marine archives collected from various sites of the Mediterranean Sea, reporting on our methodological approaches and main results.

Keywords Mediterranean Sea, Palaeoclimate reconstructions, Shallow- and deep-water corals, Vermetids, Geochemical composition

Subject codes U12007, G14003

\section{Introduction}

One of the major issues in climate studies refers to anthropogenic vs. natural changes and to predictions of the future evolution of the climate on Earth (Schneider, 2006). Numerous General Circulation Models (GCMs) have been proposed, and provide relatively good descriptions of short-term global climate variability and interactions between atmosphere, oceans, lithosphere and 
biosphere (Duffy et al., 2003; Govindasamy et al., 2003; Palmer et al., 2005). Besides computational difficulties in dealing with such complex systems, the description of which still requires considerable simplifications and assumptions, constraints on key factors for control over climate changes are often so sluggish that contrasting scenarios can be predicted (Broecker, 2001; Bradley et al., 2003; Bengtsson et al., 2006; Hunt, 2006). Are we facing a warmer period, or are the observed changes the prelude to a new glaciation? At what rate is desertification proceeding? For how long and at what rate will the sea level actually keep on rising? Is it possible to quantify the effects of El Niño and La Niña on climate changes? Are the deep ocean currents slowing down, and what will their effect on climate be?

The only way to reduce uncertainties and approximations in GCMs is to improve our knowledge on climate feedback and teleconnection mechanisms, and to test models against known long-term high-resolution time-series of the main physical and chemical parameters in marine and continental environments, such as sea surface temperature (SST) and salinity (SSS), sea-level (SL) fluctuations, seawater composition, deep water residence time, average seasonal air temperature, rainfall, vegetational cover, etc. Understanding of Holocene climate evolution may greatly help in predicting future climate changes. Beyond instrumental records, which are either limited to the last few decades or refer to a small number of stations, often with intermittent time cover, a source for palaeoclimate and palaeoenvironmental data is represented by natural archives such as tree rings, ice cores, pollens, sediments, living and sub-fossil skeletons of numerous marine organisms and the bones and teeth of continental animals and speleothems. The mid-latitude, semi-enclosed Mediterranean Sea has been highly sensitive to climatic changes during its history (Taviani, 2002; Somot et al., 2006). Therefore, the Mediterranean is an ideal test area for GCMs, since it is strongly affected by both the North Atlantic Oscillation (NAO) and the Intertropical Convergence Zone (ITCZ) (Cramp \& O'Sullivan, 1999), the position and migration of which are critical in determining climate patterns (Parrilla \& Kinder, 1987), with possible important and abrupt changes related to variations in the input of Atlantic waters with a lower salinity through the Strait of Gibraltar.

In order to examine environmental variability and its cyclical pattern in the Mediterranean Sea and to improve data to optimize GCMs, the authors, in collaboration with other international scientists, have been working over the last few years on the identification of new archives which cover different time ranges and have different temporal resolution, aiming to obtain reliable proxies for SL, SST, SSS and marine chemistry for the Mediterranean Sea, comparable to those available for tropical regions.

The successful extraction of palaeoclimatic signals from the aragonitic skeletons of shallow-water tropical zooxanthellate corals by evaluating their stable isotopes and trace and minor element compositions, was a significant 
scientific advance (Weber and Woodhead, 1972; Smith et al., 1979; Beck et al., 1992), although coral physiology seems to play an important role in controlling element uptake within the growing carbonate skeleton (Sinclair et al., 2006; Meibom et al., 2006; Gaetani \& Cohen, 2006). Results stimulated the scientific community to run parallel studies on azooxanthellate deep-water corals (Smith et al., 1997, 2000; Adkins et al., 2003; Rollion-Bard et al., 2003; Montagna et al., 2005, 2006). The aim is to decode the significant attributes of past watermasses sealed within the banded skeletons of benthic organisms located in positions (steep walls, seamounts, canyon heads, etc.) and at depths not easily monitored by routinely used proxy organisms (e.g. foraminifera, etc.). These corals may also serve as excellent indices of ocean circulation if the AMS- ${ }^{14} \mathrm{C}$ and U/Th ages gained from their skeletons are combined (Adkins et al., 1998, 2002; Schröder-Ritzrau et al., 2003).

Promising results have mainly been achieved by means of advanced analytical techniques with improved spatial resolution, detection limits, precision and accuracy in the determination of trace element concentrations and isotopic ratios by means of ICP-MS or MC-ICP-MS equipped with adequate laser beams (Sinclair et al., 1998).

The methodological approach used to verify whether specific biological archives can be used as environmental proxies in the Mediterranean Sea comprises assessment of the following points:

1) Preliminary studies:

a) availability of sampling sites;

b) biological and ecological aspects of species;

c) mineralogical and petrographic characterization.

2) Geochemical analysis of specific portions of the coral or vermetid gastropod skeleton.

3) Correlations among geochemical records and environmental parameters.

4) Comparison with other archives studied in the Mediterranean Sea

The aim of this paper is to summarize the most significant studies that we carried out on new marine archives for reconstructing climate and environmental changes in the Mediterranean Sea during the Late Quaternary.

\section{New archives for the Mediterranean Sea}

Many organisms can potentially provide information on the physical and geochemical conditions of the environment in which they live, although vital effects, microstructural features, early diagenesis and algal and other microboring organisms may render the calibration of proxies extremely difficult.

We focussed our research on species collected from various environments (shallow- and deep-sea waters) in several localities of the Mediterranean Sea 


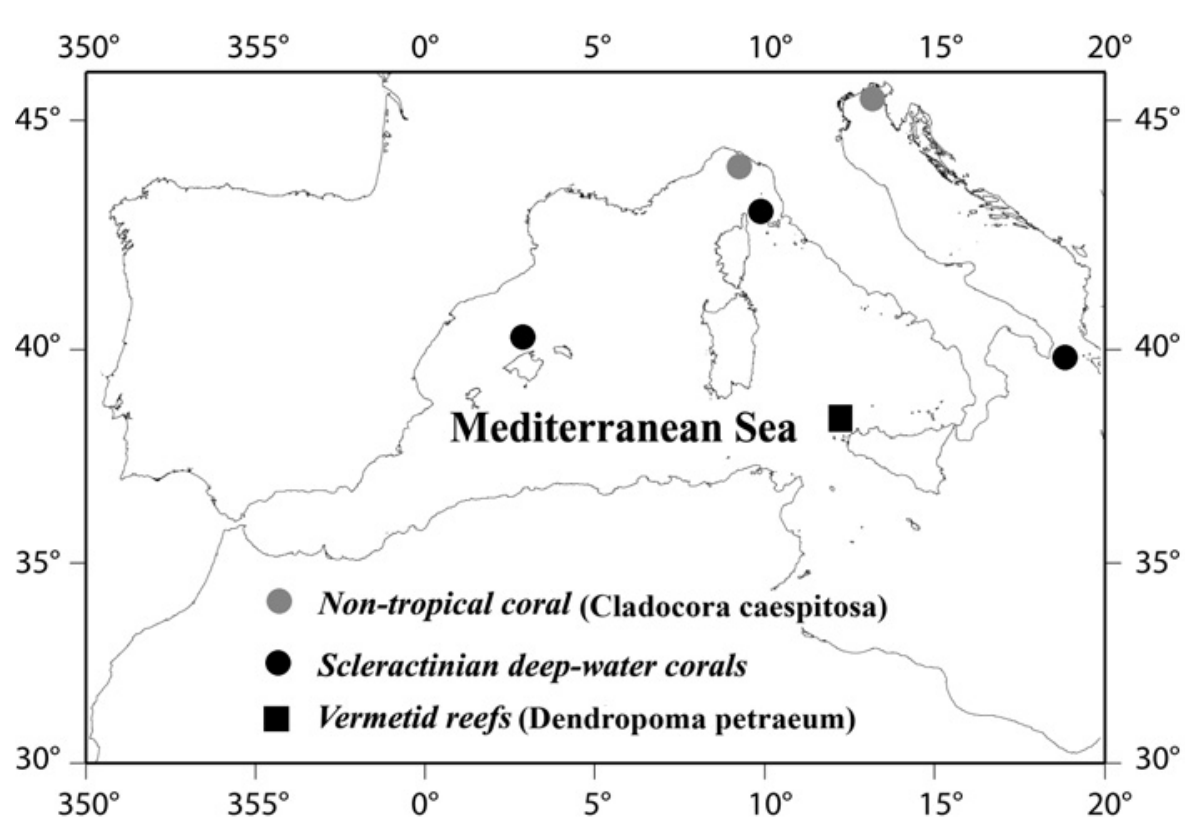

Fig. 1 Locations of the studied archives.

(Fig. 1); these organisms are characterized by internal microstructures and environmental living conditions which provided greater confidence in the possibility of obtaining time-series on unaltered samples.

\subsection{Shallow-water organisms}

\section{Last 500 years - Vermetid reefs}

Vermetid reefs are formed in intertidal or shallow-subtidal zones by thermophile gregarious and sessile gastropods belonging to the family Vermetidae. In adult organisms, the shells are cemented to rocky substrates or to older portions of the colony itself.

Vermetid reefs are found in several locations in the temperate seas over the world, e.g., the eastern and western Atlantic Ocean, i.e., along the coast of Senegal (Laborel \& Delibrias, 1976), in the Bermuda Islands (Stephenson \& Stephenson, 1954), along the coast of Brazil (Van Andel \& Laborel, 1964; Kemp \& Laborel, 1968; Laborel \& Delibrias, 1976; Angulo et al., 1999), Curaçao (Focke, 1977) and Grand Cayman (Jones and Hunter, 1995), and in the Pacific Ocean, mainly in the Hawaiian Islands (Hadfield et al., 1972).

In the Mediterranean Sea, the geographic distribution of vermetid reefs is closely linked to areas of warmer SST, mainly covering the southern Mediterranean - Syria, Lebanon, Greece, Turkey, Crete, Southern Italy, etc. (Safriel 1966, 1974; Delongeville et al., 1993; Pirazzoli \& Montaggioni, 1989, Pirazzoli 


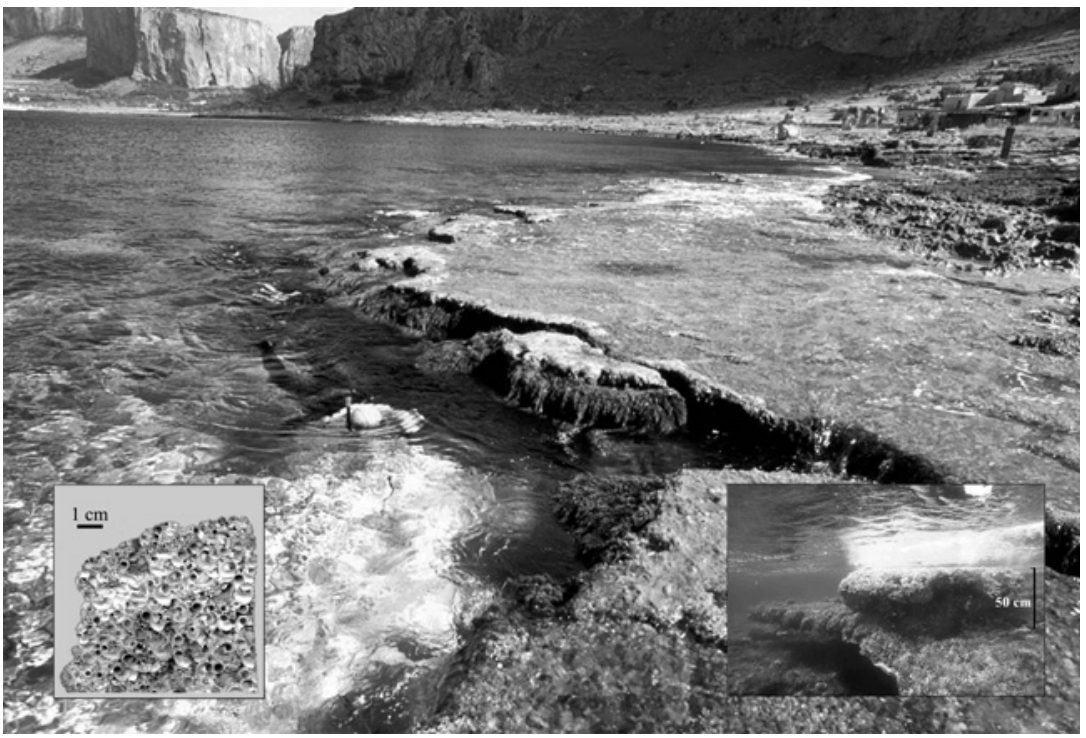

Fig. 2 A vermetid reef (platform type) along NW Sicilian coast (Castelluzzo plain, Trapani). Boxes show mushroom-type reef (right) and macro-photograph of Dendropoma petraeum colony (left).

et al., 1996; Antonioli et al., 1999, 2001; Silenzi et al., 2004). Vermetid reefs are progressively expanding from the southern Mediterranean northwards, probably as a long-term effect of the Holocene SST rise (Antonioli et al., 1999).

Of the nine known species of vermetids, Dendropoma petraeum (Monterosato, 1892) and Vermetus triquetrus (Bivona-Bernardi, 1832) are the main reef-forming ones in the Mediterranean (Sabelli et al., 1990). In particular, D. petraeum represents about $90 \%$ of all vermetid structures of the Sicilian coasts (Chemello et al., 1990). This species is a filter-feeder, protected by a thick shell and a close-fitting operculum. In the living portion, the upper aggregates lie at mean sea level and are consequently exposed during low tide and submerged during high tide. However, vermetids show a high degree of adaptation, and may also live in subtidal zones, where they feed adopting a mixed feeding strategy (Schiapparelli et al., 2006).

Living reefs start to develop on rocky shores, growing in an offshore direction (Antonioli et al., 1999) and forming bodies, the morphology of which reflects the different degrees of resistance to bedrock erosion. Platform types grow on relatively hard bedrock, and may be tens of meters wide, with remarkable lateral continuity and a maximum height of $40 \mathrm{~cm}$. Mushroom-like types develop on bedrock that is eroded at a higher rate, producing reefs made of isolated bodies (Fig. 2). In the latter case, the shape of the bio-construction is determined by continuous growth and collapse, which eventually produces structures made of large, rounded, overgrown layers. 
The use of vermetid reefs as a palaeoclimate proxy for SL and SST reconstructions is mainly related to ease of sampling, the high level of precision in determining the position of living organisms with respect to average sealevel (about $\pm 0.1 \mathrm{~m}$ in low-range tidal areas) and the feasibility of dating the carbonate skeleton by radiocarbon.

In the Mediterranean Sea, fossil vermetids are documented over the entire Holocene (Laborel \& Laborel, 1996; Antonioli et al., 1999; Laborel et al., 2000), allowing both SST and SL reconstructions back in time.

\section{Last 100-200 years - The non-tropical coral Cladocora caespitosa}

Cladocora caespitosa (Fig. 3) is a scleractinian zooxanthellate coral belonging to the Faviidae family, and is one of the most important marine bioconstructional organisms in the Mediterranean (Laborel, 1987). This species is a colonial coral widespread in the Mediterranean (Peirano et al., 2004), but it also occurs in the neighbouring eastern Atlantic, South Portugal and Moroccan coasts (Zibrowius, 1980). C. caespitosa lives in coastal waters, is confined to the euphotic zone, from depths of a few metres to $40 \mathrm{~m}$ (Morri et al., 1994), and is found on both rocky and sandy bottoms. It forms either a large number of subspherical colonies ( 10 to $30 \mathrm{~cm}$ in diameter) or massive formations reaching some decimeters in height and covering areas of several square meters (Peirano et al., 1998; Morri et al., 1994, Kühlmann, 1996; Schiller, 1993; Kružiæ \& Požar-Domac, 2003). Colonies are characterized by distinct corallites, each having its own wall, independent of the others and growing in a continuous rectilinear way, with growth rates ranging from $1.30 \mathrm{~mm} /$ year (Peirano et al., 1999) to $6.2 \mathrm{~mm} /$ year (Kružiæ \& Požar-Domac, 2003). This species generally deposits two bands per year, a high-density (HD) band during winter - at lower temperatures and sun irradiation - and a low-density (LD) band in summer - at higher temperatures and sun irradiation. Studies carried out on samples from the Ligurian Sea by Peirano et al. (1999) showed that in November, most of the corallites begin to deposit the HD band on the top of the septa, until March, when this band is fully developed, whereas the LD band is deposited from April to November.

C. caespitosa shows growth and calcification processes similar to those of tropical corals, building its aragonitic skeleton as alternating early mineralization zones (calcification centers) and aragonite fibres. It also develops a thick, continuous thecal wall, which can easily be studied by high-resolution analytical techniques.

All these aspects led us to consider this coral species as an ideal candidate to be used in detailed climate and environmental reconstructions. Recent studies have confirmed this potential (Silenzi et al., 2005; Montagna et al., 2007) and stimulated further efforts in the use of stable isotopes and trace elements on $C$. caespitosa for palaeoclimate studies. 


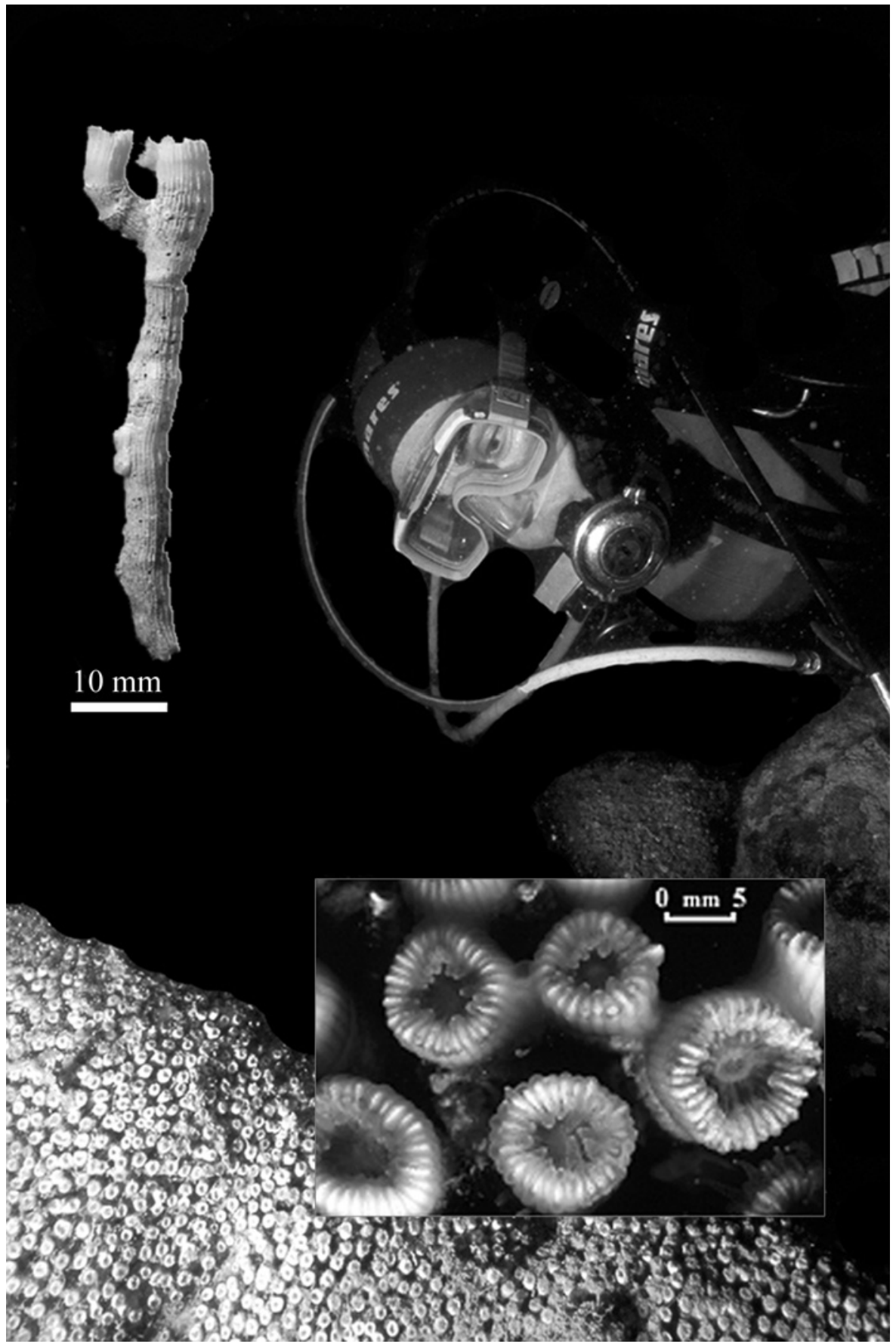

Fig. 3 Cladocora caespitosa colony from Levanto (Ligurian Sea). Boxes show macrophotographs of living corals (bottom right) and single corallite (top left). 


\subsection{The scleractinian cold-water corals Lophelia pertusa and Desmophyllum dianthus}

The cold-water corals Lophelia pertusa (Linnaeus, 1758) (Fig. 4c) and Desmophyllum dianthus (Esper, $1794=$ D. cristagalli; Milne-Edwards \& Haime, 1848) (Fig. 4a) are azooxanthellate corals, usually living at bathyal depths. In particular, Lophelia is a fast-growing organism, achieving rates higher than 1 cm/yr (Mikkelsen et al., 1982; Freiwald, 1998). Desmophyllum lives in deeper settings and grows at much slower rates (0.5-2 mm/yr; Adkins et al., 2004), but may reach up to $1 \mathrm{~cm} / \mathrm{yr}$ in some shallow eutrophic areas, such as the Chilean fjords (McCulloch et al., 2005). Both scleractinians display a quasicosmopolitan distribution which includes the Mediterranean Sea (Freiwald, 1998, 2002; Taviani et al., 2005a). Within the Mediterranean, where they have been discontinuously present since the middle Miocene (Taviani et al., 2005b),

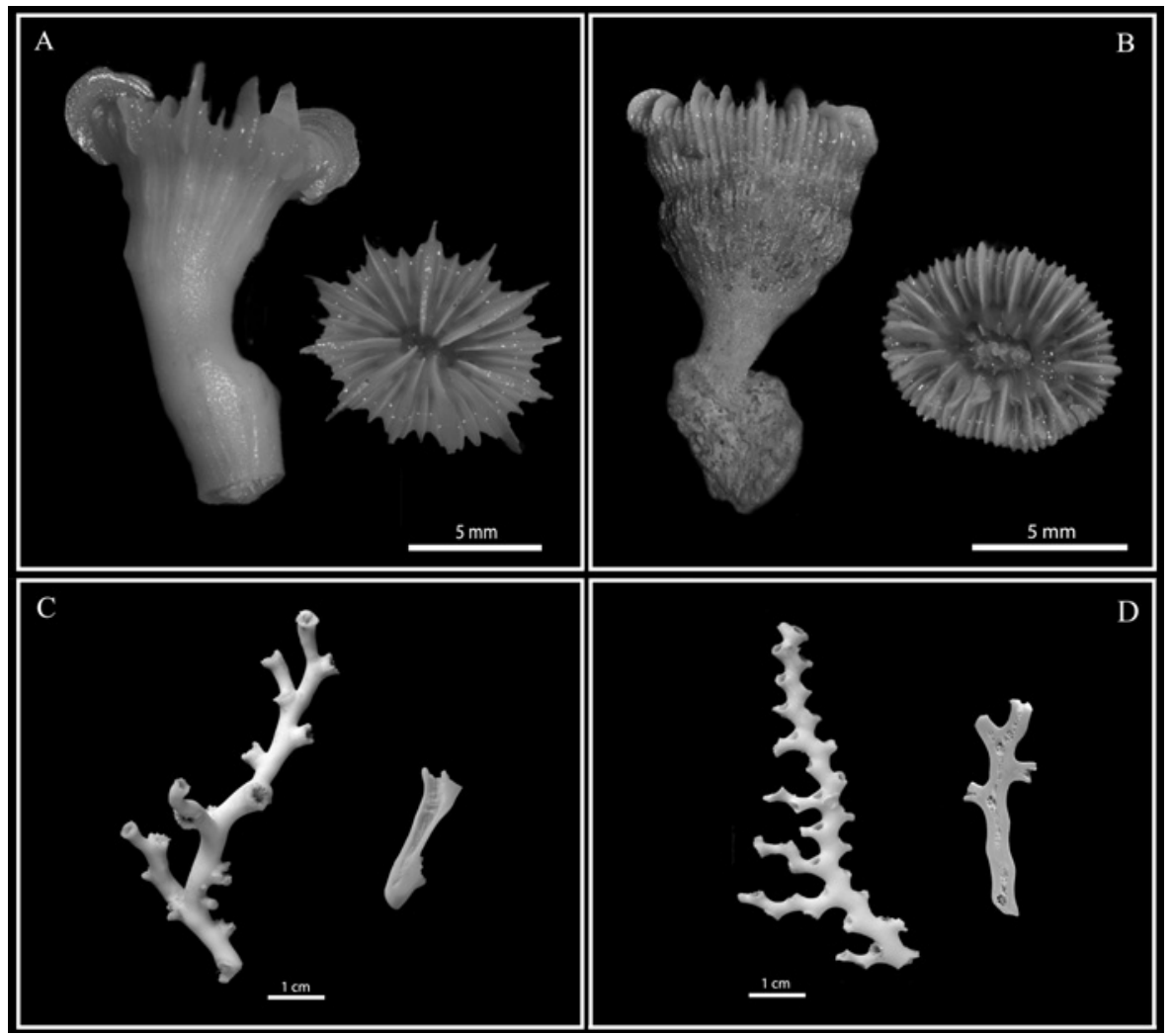

Fig. 4 Main scleractinian deep-water corals found in the Mediterranean: a) Desmophyllum dianthus (living specimen collected in the Balearic Sea); b) Caryophillia smithii (living specimen collected in the Balearic Sea); c) Lophelia pertusa (living specimen collected in Santa Maria di Leuca); d) Madrepora oculata (fossil specimen collected in the Balearic Sea). 
these taxa are only found at depths in excess of $\sim 250-300 \mathrm{~m}$, down to $\sim 1000$ $\mathrm{m}$ (Lophelia) and $\sim 2500 \mathrm{~m}$ (Desmophyllum), respectively. Although these species have been identified throughout the basin, most occurrences refer to still-submerged glacial Pleistocene situations (Remia \& Taviani, 2005; Taviani et al., 2005b) and examples of living individuals, especially Lophelia, are quite rare (Taviani et al., 2005a,b).

L. pertusa is a colonial coral which precipitates an aragonitic exoskeleton with mucus-induced increments, consisting of a thick wall, clearly made up of rhythmic bands, producing rigid coral frameworks (Freiwald et al., 1997).

$D$. dianthus is a solitary coral, with a cone-shaped calyx, large aragonitic septa, and a thecal wall. The vertical septa show successive lamellae (about 10 $\mu \mathrm{m}$ long) which are not unequivocally interpreted and whose chronological significance still remains to be established (Lazier et al., 1999).

Both $L$. pertusa and $D$. dianthus are excellent candidates for evaluating high-resolution palaeoceanographic and palaeoclimate changes, because they systematically incorporate numerous key trace elements and stable isotopes in bands or layers, which can be subsampled and are sufficiently uranium-rich to be suitable for ${ }^{230} \mathrm{Th}-{ }^{234} \mathrm{U}$ dating.

In order to fully evaluate the palaeoclimate potential of such deep-water corals in providing oceanographic reconstructions of the past history of the Mediterranean, we examined numerous samples of living and dead L. pertusa and $D$. dianthus from various locations - from west to east: Balearic and Tyrrhenian Seas, Strait of Sicily, Ionian Sea - analyzed by high-resolution techniques (Montagna et al., 2004; 2005; 2006).

\section{Main results}

\section{Last 500 years - Vermetid reefs}

Antonioli et al. (1999) reconstructed sea-level rise curves along tectonically stable areas of northern Sicily using radiocarbon dating on $D$. petraeum species. They compared present mean sea-level with the depth of the fossil samples, and suggested a sea-level rise of $40 \pm 8 \mathrm{~cm}$ in the last $430 \pm 30$ years BP. This type of information is useful for calibrating Holocene sea-level rise curves, for which instrumental data derived from tide gauges only go back for the last two centuries, and shallow-water corals only provide scanty data over the last $6 \mathrm{ka}$ BP (Bard et al., 1996).

Further investigations on samples from the same colony demonstrated the potential of $D$. petraeum in evaluating SST changes by measuring the stable isotopic composition of vermetid (Silenzi et al., 2004). These authors were able to identify a record of the cold period known as the Little Ice Age (LIA), followed by a warming trend which characterized the $20^{\text {th }}$ century (Fig. 5). They also showed that SSTs were warmer today than during the second half of the 


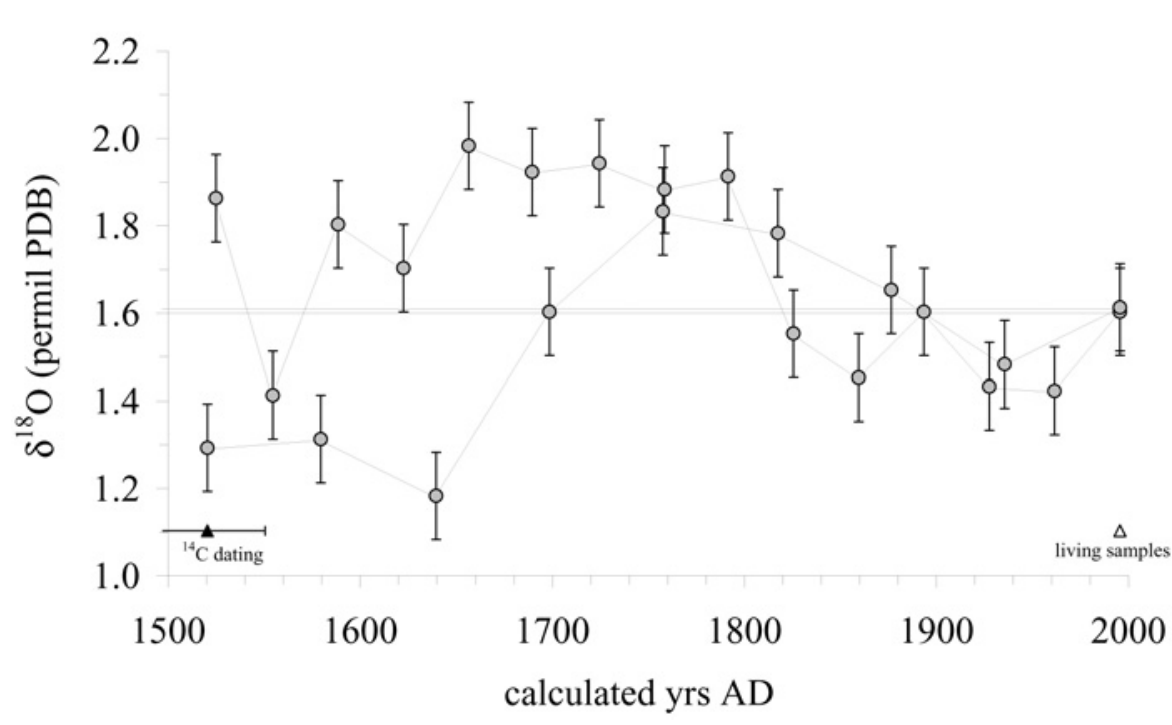

Fig. $5 \delta^{18} \mathrm{O}$ variations of two Sicilian vermetid colonies (Dendropoma petraeum), spanning the time-period 1550-2000 AD (data from Silenzi et al., 2004).

The two horizontal grey lines at 1.60 and $1.61 \%$ represent the $\delta^{18} \mathrm{O}$ mean value of living vermetids at the sampling site. The ${ }^{14} \mathrm{C}$ age (black circle with horizontal grey error bar) refers to a sample located in the oldest portion of one of the two colonies and therefore represents the beginning of the reef growth.

$16^{\text {th }}$ century, fitting data by Keigwin (1996) - i.e., the temperature dropped during the LIA and rose again afterwards - and estimated a temperature difference of about $1.99 \pm 0.37{ }^{\circ} \mathrm{C}$ between LIA SST and present-day SST. In addition, they showed that the modern rise in temperature ended around the years 19301940, and that a relatively cold period followed between 1940 and 1995. If we consider the aragonite mineralogy of $D$. petraeum, as reported by Triolo et al. (2003), and we apply the aragonite vs. temperature fractionation equation $\left[\mathrm{T}=20.6-4.34 \cdot\left(\delta^{18} \mathrm{O}_{\text {carbonate }}-\delta^{18} O_{\text {seawater }}\right)\right]$ with a $\delta^{18} \mathrm{O}_{\text {seawater }}=+1.3 \%$ V-SMOW (Pierre 1999), we obtain a reconstructed temperature ranging between 17.6 and $21.1^{\circ} \mathrm{C}$. The temperature range plots somewhere in the middle of the present-day annual temperature cycle characteristic of the sampling site. Therefore, considering that each sample represents an average of about 30-50 years (Silenzi et al., 2004), each calculated temperature value corresponds to a multi-decennial temperature average.

\section{Last 100 years - The non-tropical coral Cladocora caespitosa}

Recently, Silenzi et al. (2005) targeted for the first time the non-tropical coral C. caespitosa as a potential climate archive using stable isotopes and trace elements. HD bands were collected on an 18-cm long corallite, which had been continuously growing since 1906 , and analyzed it for $\delta^{18} \mathrm{O}, \delta^{13} \mathrm{C}, \mathrm{Sr} / \mathrm{Ca}$ and 
$\mathrm{Mg} / \mathrm{Ca}$. This coral was collected alive on the continental shelf of the Ligurian Sea (north-western Mediterranean) at a water depth of $28 \mathrm{~m}$.

A significant correlation was derived between $\mathrm{Sr} / \mathrm{Ca}$ and the Integrated Global Ocean Service System (IGOSS) SST for the last 20 years, resulting in the following equation: $\mathrm{Sr} / \mathrm{Ca}(\mathrm{mmol} / \mathrm{mol})=11.25( \pm 0.38)-0.079( \pm 0.026)$ SST $\left({ }^{\circ} \mathrm{C}\right)$.

The calculated calibration displayed a slope (-0.079) comparable with those of equations obtained for tropical corals, suggesting similar mechanisms for Sr uptake among tropical and temperate corals. $\delta^{18} \mathrm{O}$ and $\mathrm{Mg} / \mathrm{Ca}$ showed a weaker correlation with SST, suggesting that the former is partially controlled by $\delta^{18} \mathrm{O}_{\text {seawater }}$ and the latter is influenced by the presence of organic matter and/or microborings.

These promising preliminary results established that $C$. caespitosa might work as a palaeoclimate archive capable of providing high-resolution SST time-series. Further research was carried out by Montagna et al. (2007) on the applicability of trace elements within the skeletal aragonite of C. caespitosa. The above authors studied a $\sim 4-\mathrm{cm}$ long corallite from the Natural Marine Reserve of Miramare (NMRM) (Gulf of Trieste, north-eastern Adriatic), with a high-resolution analytical technique (ICPMS laser ablation system) at the Research School of Earth Sciences, Australian National University (ANU). This technique enabled then to overcome the problem commonly faced in bulk analysis studies, in which large pieces of coral skeleton may contain structurally and diagenetically complex components.

$\mathrm{Sr} / \mathrm{Ca}, \mathrm{B} / \mathrm{Ca}, \mathrm{Mg} / \mathrm{Ca}, \mathrm{U} / \mathrm{Ca}$ and $\mathrm{Ba} / \mathrm{Ca}$ showed correlated patterns of covariance, $\mathrm{Sr} / \mathrm{Ca}, \mathrm{B} / \mathrm{Ca}, \mathrm{U} / \mathrm{Ca}$ and $\mathrm{Ba} / \mathrm{Ca}$ being strongly positively correlated and $\mathrm{Mg} / \mathrm{Ca}$ showing negative correlations with most of the other elements. A significant relationship was found between both $\mathrm{B} / \mathrm{Ca}$ and $\mathrm{Sr} / \mathrm{Ca}$ and the measured SSTs, collected a few tens of meters from the sampling location, over a period of 6 years. The following equations were calculated: $\mathrm{B} / \mathrm{Ca}$ $(\mathrm{mmol} / \mathrm{mol})=1.24( \pm 0.03)-0.024( \pm 0.001) \mathrm{SST}\left({ }^{\circ} \mathrm{C}\right) ; \mathrm{Sr} / \mathrm{Ca}(\mathrm{mmol} / \mathrm{mol})$ $=10.50( \pm 0.13)-0.073( \pm 0.006) \mathrm{SST}\left({ }^{\circ} \mathrm{C}\right)$ (Montagna et al., 2007). In particular, $\mathrm{B} / \mathrm{Ca}$ ratios, tuned to fine scale variations in SST, showed a high degree of correlation $(\mathrm{r}=-0.856, \mathrm{n}=136)$ with SSTs. The best $\mathrm{B} / \mathrm{Ca}$ vs. SST fitting model indicates that coral calcification only occurs above a minimum temperature threshold of $\sim 14^{\circ} \mathrm{C}$ (Fig. 6).

$\mathrm{Ba} / \mathrm{Ca}$ ratios, together with those of other elements, were then correlated with salinity and river discharge variations, in order to test the influence of various environmental parameters other than temperature on element uptake in the coral aragonite. $\mathrm{Ba} / \mathrm{Ca}$ was partially correlated with flood events in the river Isonzo. Periods of high river discharge probably cause a decrease in coral $\mathrm{Ba} / \mathrm{Ca}$, probably as an effect of dilution of seawater barium. 


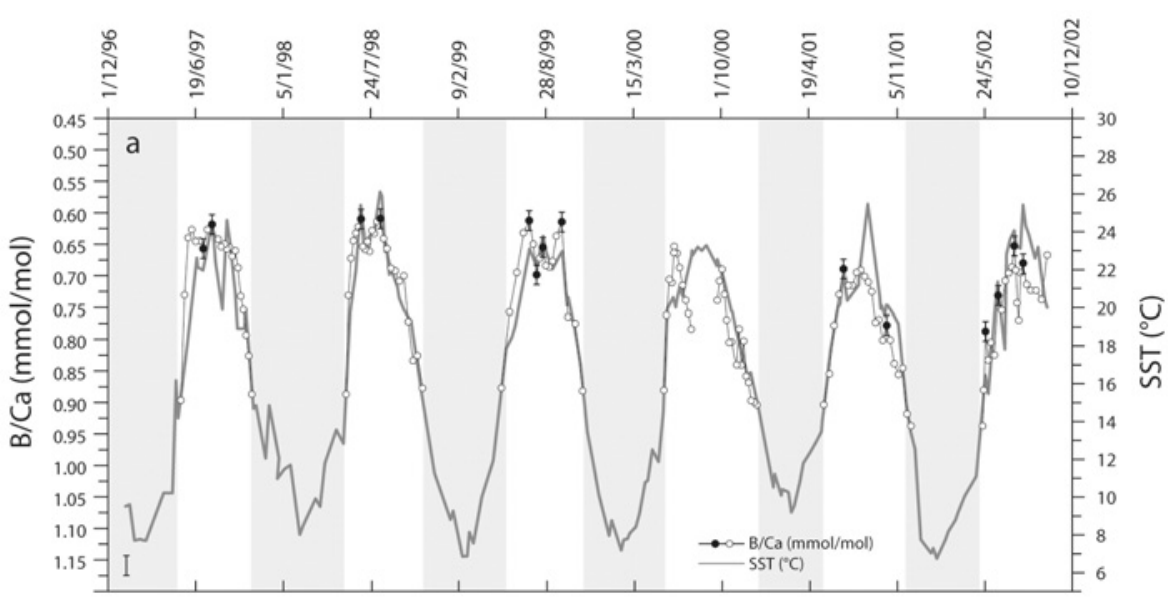

Fig. 6 Comparison between B/Ca ratios and instrumental SST data during the period 19972002. Error bar refers to B/Ca analytical precision. Gray shaded areas correspond to growth interruption during winter time when temperature drops below $14^{\circ} \mathrm{C}$. Filled circles represent distinctive marker points common to B/Ca and SST time-series, with error bars. (data from Montagna et al., 2007).

At present, tens of samples are being geochemically studied by LA-ICPMS, all collected from various localities in the Mediterranean, where environmental parameters have been measured in the last few decades. These studies will produce precise calibrations for each of these localities, for greater confidence in the applicability of the proxy, and subsequently allow the resulting equations to be applied to fossil records.

\section{Last 27,000 years - Deep-water corals}

We systematically measured trace and minor element ratios $\mathrm{Mg} / \mathrm{Ca}, \mathrm{Ba} / \mathrm{Ca}$, $\mathrm{Sr} / \mathrm{Ca}, \mathrm{U} / \mathrm{Ca}, \mathrm{B} / \mathrm{Ca}, \mathrm{Mn} / \mathrm{Ca}$ and $\mathrm{P} / \mathrm{Ca}$ in deep-water corals, in order to detect coherent high-resolution signals stored in their banded skeletons (Montagna et al., 2004, 2005). Although the interpretation of such geochemical signals is not always straightforward and requires supplemental analytical work to decode any hidden palaeoclimatic significance, phosphorus content within Desmophyllum aragonite did represent an exceptionally reliable proxy for water fertility, and thus assumed the role of new palaeoceanographic tool (Montagna et al., 2006; Fig. 7). Instead, interpretation of geochemical patterns from the framework-forming species Lophelia pertusa and Madrepora oculata (Fig. 4d) and the solitary coral Caryophyllia smithii (Fig. 4b) were extremely complicated, due to their complex skeletal morphologies. Laser ablation profiles along two parallel portions of the thecal walls of Lophelia pertusa showed little reproducibility, and seemed to be affected mainly by the mixture of different coral microstructures - i.e., calcification centers and fibrous aragonite - which 


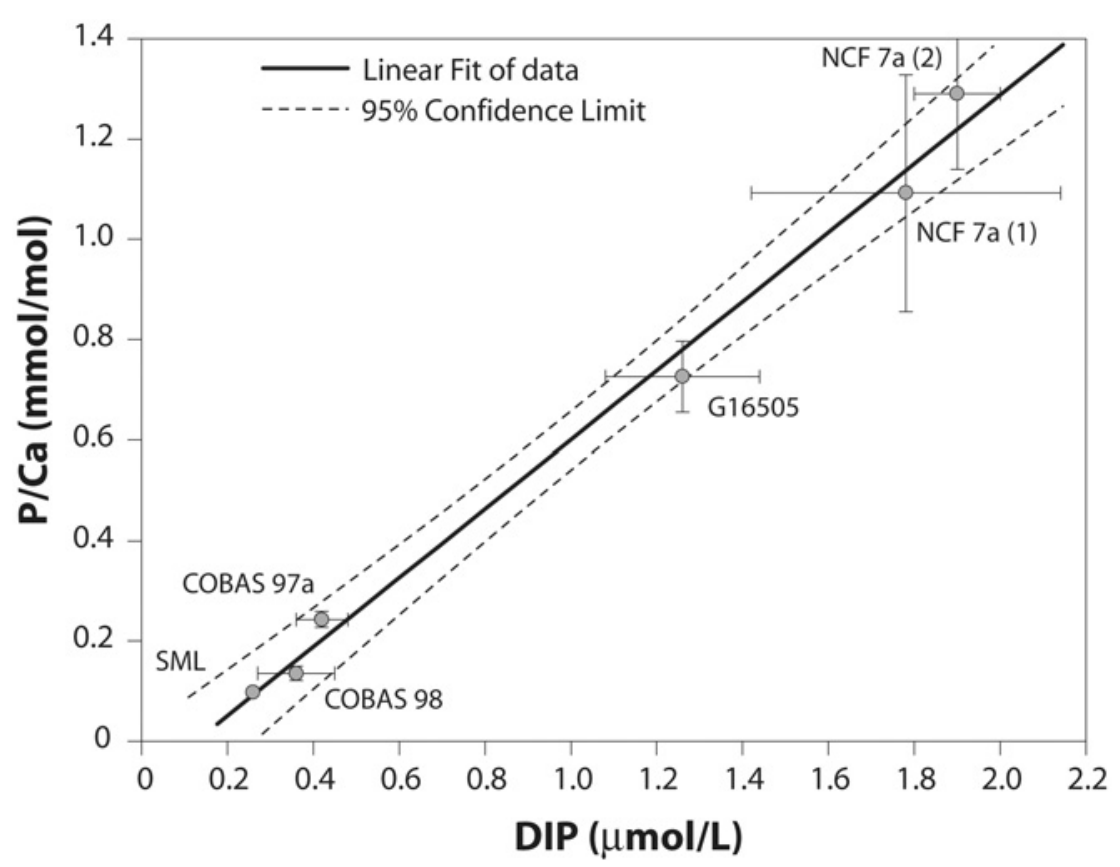

Fig. 7 Linear regression of $\mathrm{P} / \mathrm{Ca}$ ratios in coral aragonite of Desmophyllum dianthus vs. measured dissolved inorganic phosphorus (from Montagna et al., 2006).

are extremely difficult to discriminate in these species. L. pertusa is at present the main target for further detailed studies, with the aim of discriminating environmental signals and "vital effects" by combining different trace/minor elements and stable isotopes (López Correa et al., submitted).

Lastly, it should be mentioned that high-resolution studies of the growth bands of the large Atlantic-Mediterranean limid Acesta excavata (Fabricius, 1779) often associated with deep-water coral banks (López Correa et al., $2005 a, b)$, have shown very promising results in terms of reconstructing palaeotemperatures and nutrient contents.

\section{Conclusions}

The present paper reviews the main results and perspectives of the research of an international research team (Tab. 1) regarding new high-resolution natural archives in the Mediterranean. These results will provide tools for reconstructing patterns of decennial climatic variability and estimates of the geochemical properties of shallow and deep-sea waters.

The vermetid $D$. petraeum seems to be a reliable palaeoclimatic indicator for SL and SST trends over the last 500 years, when anthropogenic activities may have considerably altered natural biogeochemical cycles and thus 
Table 1 Description of new archives for Mediterranean Sea.

\begin{tabular}{|c|c|c|c|c|c|}
\hline Proxy & Environment & $\begin{array}{l}\text { Established } \\
\text { archive } \\
\text { time } \\
\text { frame }\end{array}$ & $\begin{array}{l}\text { Temporal } \\
\text { resolu- } \\
\text { tion }\end{array}$ & $\begin{array}{l}\text { Parameter } \\
\text { recon- } \\
\text { structed }\end{array}$ & $\begin{array}{l}\text { Main } \\
\text { references }\end{array}$ \\
\hline $\begin{array}{l}\text { Vermetids } \\
\text { (Dendropoma } \\
\text { petraeum) }\end{array}$ & $\begin{array}{l}\text { Intertidal } \\
\text { areas in } \\
\text { warm wa- } \\
\text { ters }\end{array}$ & $\begin{array}{l}1400 \mathrm{AD} \\
\text { to present }\end{array}$ & $30-40$ yrs & $\begin{array}{l}\text { Sea-level; } \\
\text { SST }\end{array}$ & $\begin{array}{l}\text { Antonioli et al., } \\
1999 \\
\text { Silenzi et al., } \\
2004\end{array}$ \\
\hline $\begin{array}{l}\text { Non-tropical } \\
\text { coral (Cladocora } \\
\text { caespitosa) }\end{array}$ & $\begin{array}{l}\text { From } 0 \\
\text { to } \sim 40 \mathrm{~m} \\
\text { water depth }\end{array}$ & $\begin{array}{l}1850 \mathrm{AD} \\
\text { to present }\end{array}$ & $\begin{array}{l}\text { Monthly } \\
\text { to weekly }\end{array}$ & $\begin{array}{l}\text { SST; sea- } \\
\text { water } \\
\text { chemistry }\end{array}$ & $\begin{array}{l}\text { Silenzi et al., } \\
2005 \text { Montagna } \\
\text { et al., } 2007\end{array}$ \\
\hline $\begin{array}{l}\text { Deep-sea corals } \\
\text { (Lophelia per- } \\
\text { tusa, Madrepora } \\
\text { oculata, Desmo- } \\
\text { phyllum di- } \\
\text { anthus) }\end{array}$ & $\begin{array}{l}\text { From } \\
\sim 200 \mathrm{~m} \text { to } \\
\sim 1200 \mathrm{~m} \\
\text { water depth }\end{array}$ & $\begin{array}{l}1950 \mathrm{AD} \\
\text { to present }\end{array}$ & $\begin{array}{l}\text { Seasonal } \\
\text { to annual } \\
\text { minus- } \\
\text { colo }\end{array}$ & $\begin{array}{l}\text { Sea-water } \\
\text { chemistry; } \\
\text { biological } \\
\text { productivity }\end{array}$ & $\begin{array}{l}\text { Montagna et } \\
\text { al., 2005; } 2006\end{array}$ \\
\hline
\end{tabular}

enhanced the greenhouse effect. This marker may be successfully applied not only to the warm waters of the Mediterranean, but also in other temperate areas around the world where vermetids are known to live.

The characterization in C. caespitosa of all the main isotopic and geochemical signals which are typically studied in tropical corals $\left(\delta^{18} \mathrm{O}, \mathrm{Sr} / \mathrm{Ca}\right.$, $\mathrm{Mg} / \mathrm{Ca}, \mathrm{B} / \mathrm{Ca}, \mathrm{U} / \mathrm{Ca}$ ) provided evidence that this non-tropical coral represents a new, potentially important, high-resolution ( $\sim$ weekly) archive for climate variability in the Mediterranean. This new proxy is not affected by mean annual climate features, either short-term perturbations in physical environmental variables or growth rate fluctuations. In particular, $\mathrm{B} / \mathrm{Ca}$ and $\mathrm{Sr} / \mathrm{Ca}$ ratios show a high degree of correlation with SST, representing ideal palaeothermometers for SST.

Phosphorus incorporated within the skeleton of cosmopolitan cold-water corals like Desmophyllum dianthus was found to be directly correlated to the ambient seawater phosphorus concentration, demonstrating the potential of these organisms as proxies for ocean productivity, nutrient residence times and sources of deep-water masses, both in the present and in the past history of the Mediterranean.

Acknowledgements. This research benefited by funds from ESF Euromargins 'Moundforce', EU 'Hermes', Firs “Micena” and Firb 'Aplabes' programs. Financial support was also provided by the University of Padova, the Short-Term Mobility Program of the CNR and the Ermenegildo Zegna Foundation, which are all kindly acknowledged. This is IGM contribution n. 1604. We thank T. Corrège and M. López Correa for thoughtful and helpful comments. 


\section{References}

1. Adkins JF, Cheng H, Boyle EA, Druffel ERM, Edwards LRL (1998) Deep-sea coral evidence for rapid change in ventilation of the deep North Atlantic 15,400 years ago. Science 280: 725-728

2. Adkins JF, Griffin S, Kashgarian M, Cheng H, Druffel ERM, Boyle EA, Edwards LRL, Shen CC (2002) Radiocarbon dating of deep-sea corals. Radiocarbon 44: 567-580

3. Adkins JF, Boyle EA, Curry WB, Lutringer A (2003) Stable isotopes in deep-sea corals and a new mechanism for "vital effects". Geochimica et Cosmochimica Acta 67: 1129-1143

4. Adkins JF, Henderson GM, Wang S-L, O'Shea A, Mokadem, F (2004) Growth rates of the deep-sea scleractinia Desmophyllum cristagalli and Enallopsammia rostrata. Earth and Planetary Science Letters 227: 481-490

5. Alibert C, McCulloch MT (1997) Strontium/Calcium ratios in modern Porites corals from the Great Barrier Reef as a proxy for sea surface temperature: calibration of the thermometer and onitoring of ENSO. Paleoceanography 12: 345-363

6. Angulo RJ, Giannini PCF, Suguio K, Pessenda LCR (1999) Relative sea-level changes in the last 5500 years in southern Brazil (Laguna-Imbituba region, Santa Catarina State) based on vermetid 14C ages. Marine Geology 159: 323-339

7. Antonioli F, Chemello R, Improta S, Riggio S (1999) Dendropoma lower intertidal reef formations and their palaeoclimatological significance, NW Sicily. Marine Geology 161: $155-170$

8. Antonioli F, Silenzi S, Frisia, S (2001) Tyrrhenian Holocene palaeoclimate trends from spelean serpulids. Quaternary Science Reviews 20: 1661-1670

9. Bard E, Hamelin B, Arnold M, Montaggioni L, Cabioch G, Faure G, Rougerie F (1996) Deglacial sea-level record from Tahiti corals and the timing of global meltwater discharge. Nature 382: 241-244

10. Beck JW, Edwards RL, Ito E, Taylor FW, Récy J, Rougerie F, Joannot P, Henin C (1992) Sea-surface temperature from coral skeletal strontium/calcium ratios. Science 257: 644647

11. Bengtsson L, Hodges KI, Roeckner E, Brokopf R (2006) On the natural variability of the pre-industrial European climate. Climate Dynamics 27: 743-760

12. Bivona-Bernardi A (1832) Caratteri dei vermeti desunti da cinque specie che abitano nel mare di Palermo. Effemeridi scientifiche e letterarie per la Sicilia, 1, 2, 3

13. Bradley RS, Hughes MK, Diaz HF (2003) Climate in medieval time. Science 302: 404-405

14. Broecker WS (2001) Was the medieval warm period global? Science 291: 1497-1499

15. Chemello R, Pandolfo A, Riggio S (1990) Le biocostruzioni a Molluschi Vermetidi nella Sicilia Nord-Occidentale. Atti 53 Congresso UZI, Palermo.

16. Cramp A, O’Sullivan G (1999) Neogene sapropels in the Mediterranean: a review. Marine Geology 153: 11-28

17. Delongeville R, Laborel J, Pirazzoli P, Sanlaville P, Arnold M, Bernier P, Evin J, Montaggioni L (1993) Les variations récentes de la ligne de rivage sur le littoral Syrien. Quaternaire 4: $45-53$

18. Duffy PB, Govindasamy B, Iorio JP, Milovich J, Sperber KR, Taylor KE, Wehner MF, Thompson SL (2003) High-resolution simulations of global climate, part 1: present climate. Climate Dynamics 21: 371-390

19. Epstein S, Buchsbaum R, Lowenstam HA, Urey HC (1953) Revised carbonate-water isotopic temperature scale. GSA Bulletin 64: 1315-1325

20. Esper EJC (1794) Fortsetzungen der Pflanzenthiere. Nürnberg. Vol. 1, part 1-2, pp. 64

21. Fabricius JC (1779) Reise nach Norwegen mit Bemerkungen aus der Naturhistorie und Oekonomie. Hamburg, Reise Norwegen 
22. Focke JW (1977) The effect of a potentially reef-building vermetid community on an eroding limestone coast, Curacao, Netherland Antilles. Proceedings of the 3rd International Coral Reef Symposium, Miami, Vol. 1 239-245

23. Freiwald A (1998) Geobiology of Lophelia pertusa (Scleractinia) reefs in the north Atlantic. Habilitation thesis, Univ. Bremen pp. 116

24. Freiwald A (2002) Reef-Forming Cold-Water Corals. In: Wefer G, Billett D, Hebbeln D, Jørgensen BB, Schlüter M, van Weering T (eds.) Ocean Margin Systems, Springer: Berlin-Heidelberg 365-385

25. Freiwald A, Henrich R, Paetzold J. (1997) Anatomy of a deep-water coral reef mound from Stjernsund, West-Finnmark, northern-Norway. SEPM, Special Publication 56: 141-161

26. Gaetani GA, Cohen AL (2006) Element partitioning during precipitation of aragonite from seawater: a framework for understanding paleoproxies. Geochimica et Cosmochimica Acta 70: 4617-4634

27. Govindasamy B, Duffy PB, Coquard J (2003) High-resolution simulations of global climate, part 2: effects of increasing greenhouse cases. Climate Dynamics 21: 391-404

28. Grottoli AG (1999) Variability of stable isotopes and maximum linear extension in reefcoral skeletons at Kaneohe Bay, Hawaii. Marine Biology 135: 437-449

29. Hadfield MG, Kay EA, Gillette MU, Lloyd MC (1972) The Vermetidae (Mollusca Gastropoda) of the Hawaiian Islands. Marine Biology 12: 81-98

30. Hunt BG (2006) The Medieval Warm Period, the Little Ice Age and simulated climatic variability. Climate Dynamics 27: 677-694 DOI 10.1007/s00382-006-0153-5.

31. Jones B, Hunter I (1995) Vermetid buildups from Grand Cayman, British West Indies. Journal of Coastal Research 4: 973-983

32. Keigwin LD (1996) The Little Ice Age and medieval warm period in the Sargasso Sea. Science 274: 1504-1508

33. Kemp M, Laborel J (1968) Formations de vermets et d'algues calcaires sur les cotes du Bresil. Rec. Trav. Stat. Mar. Endoume 43, 59: 9-23

34. Kružiæ P, Požar-Domac A (2003) Banks of the coral Cladocora caespitosa (Anthozoa, Scleractinia) in the Adriatic Sea. Coral Reefs 22: 536

35. Kûhlmann DHH (1996) Preliminary report on Holocene submarine accumulation of Cladocora caespitosa (L., 1767) in the Mediterranean. Göttinger Arb Geol. Pälont. Sb2: 65-69

36. Laborel J (1987) Marine biogenic constructions in the Mediterranean, a review. Rep. Sci. Par natl. Port-Cros 13: 97-126

37. Laborel J, Delibrias G (1976) Niveaux marins récents à vermetidae du littoral ouest Africain. Assoc. Senegal. Etude Quat. Afr. Bull. 47: 97-110

38. Laborel J, Laborel-Deguen F (1996) Biological indicators of Holocene sea level and climatic variations on rocky coasts of tropical and subtropical regions. Quaternary International 31: 53-60

39. Lazier AV, Smith JE, Risk MJ, Schwarcz HP (1999) The skeletal structure of Desmophyllum cristagalli: the use of deep-water corals in sclerochronology. Lethaia 32: 119-130

40. Linnaeus C (1758) Systema naturae per regna tria naturae, secundum classes, ordines, genera, species, cum characteribus, differentiis, synonymis, locis. Regnum Animale. $10^{\text {th }}$ ed. W. Engelmann, Lipsiae

41. López Correa M, Freiwald A, Taviani M (2005a). Stable oxygen and carbon isotope composition of extant North Atlantic Acesta spp. (Bivalvia: Limidae), provide high-resolution environmental archives for cold-water coral habitats. Third International Symposium on Deep-Sea Corals, Miami, November 2005

42. López Correa M, Freiwald A, Hall-Spencer J, Taviani M (2005b). Distribution and habitats of Acesta excavata (Bivalvia: Limidae), with new data on its shell ultrastructure. In: Freiwald A, Roberts M, (eds.) Deep-water Corals and Ecosystems, Springer-Verlag, 173-205 
43. López Correa M, Montagna P, Vendrell B, McCulloch M, Taviani M (submitted). Stable isotopes $\left(\delta^{18} \mathrm{O}, \delta^{13} \mathrm{C}\right)$, trace and minor element compositions of Last Glacial to Recent scleractinians and bivalves at Santa Maria di Leuca deep-water coral province, Ionian Sea. Deep-Sea Research, submitted

44. McCulloch M, Montagna P, Försterra G, Mortimer G, Häussermann V, Mazzoli C (2005) Uranium-series dating and growth rates of the cold-water coral Desmophyllum dianthus from the Chilean Fjords. Program and Abstract Book of the Third International Symposium on Deep-Sea Corals, Miami, pp. 191

45. Meibom A, Yurimoto H, Cuif J-P, Domart-Coulon I, Houlbreque F, Constantz B, Dauphin Y, Tambutté E, Tambutté S, Allemand D, Wooden J, Dunbar R (2006) Vital effects in coral skeletal composition display strict three-dimensional control. Geophysical Research Letters 33, L11608, DOI:10.1029/2006GL025968

46. Metalpa RR, Peirano A, Morri C, Bianchi CN (1999) Coral calcification rates in the Mediterranean Scleractinian coral Cladocora caespitosa (L., 1767). Atti Associazione Italiana Oceanologia e Limnologia 13, 1, 291-299

47. Mikkelsen N, Erlenkenkeuser E, Killingley JS, Berger WH (1982) Norwegian corals: radiocarbon and stable isotopes in Lophelia pertusa. Boreas 11: 163-171

48. Milne-Edwards H, Haime J (1848) Recherches sur les Polypiers, deuxième mémoire, Monographie des Turbinolides. Annales des Sciences Naturelles, Zoologie 9: 211-344

49. Montagna P, McCulloch M, Taviani M, Remia A, Mazzoli C (2004). Laser ablation systematics in deep-water corals (Desmophyllum dianthus) from the Mediterranean Sea and the Pacific Ocean. 8th International Conference on Paleoceanography, 5-10 September 2004, Biarritz (France)

50. Montagna P, McCulloch M, Taviani M, Remia A, Rouse G (2005) High-resolution trace and minor element compositions in deep-water solitary scleractinian corals (Desmophyllum dianthus) from the Mediterranean Sea and the Great Australian Bight. In: Freiwald A, Roberts M (eds.) Deep-water Corals and Ecosystems. Springer-Verlag: 1109-1126

51. Montagna P, McCulloch M, Taviani M, Mazzoli C, Vendrell B (2006) Phosphorus in coldwater corals as a proxy for seawater nutrient chemistry. Science 312: 1788-1791

52. Montagna P, McCulloch M, Mazzoli C, Silenzi S, Odorico R (2007) The non-tropical coral Cladocora caespitosa as the new climate archive for the Mediterranean Sea: high-resolution ( weekly) trace element systematics. Quaternary Science Review 26: 441-462

53. Monterosato MTA (1892) Monografia dei vermeti del Mediterraneo. Bull. Soc. Malacol. Ital. 17: 7-48

54. Morri C, Peirano A, Bianchi CN, Sassarini M (1994) Present-day bioconstructions of the hard coral, Cladocora caespitosa (L.) (Anthozoa, Scleractinia), in the Eastern Ligurian Sea (NW Mediterranean). Biologia Marina Mediterranea 1: 371-372

55. Palmer TN, Shutts GJ, Hagedorn R, Doblas-Reyes FJ, Jung T, Leutbecher M (2005) Representing model uncertainty in weather and climate prediction. Annual Review of Earth and Planetary Science 33: 163-193

56. Parrilla G, Kinder TH (1987) Oceanografia fisica del mar de Alboran. Boletın del Instituto Espanol de Oceanografia 4: 133-165

57. Peirano A, Morri C, Mastronuzzi G, Bianchi CN (1998) The coral Cladocora caespitosa (Anthozoa, Scleractinian) as a bioherm builder in the Mediterranean Sea. Memorie Descrittive Carta Geologica d'Italia 52: 59-74

58. Peirano A, Morri C, Bianchi CN (1999) Skeleton growth and density pattern of the temperate, zooxanthellate scleractinian Cladocora caespitosa from the Ligurian Sea (NW Mediterranean). Marine Ecology Progress Series 185: 195-201

59. Peirano A, Morri C, Bianchi CN, Aguirre J, Antonioli F, Calzetta G, Carobene L, Mastronuzzi G, Orrù $\mathrm{P}$ (2004) The Mediterranean coral Cladocora caespitosa: a proxy for past climate fluctuations? Global and Planetary Change 40: 195-200 
60. Pirazzoli PA, Montaggioni LF (1989) Crustal block movements from Holocene shorelines: Rhodes Island, Greece. Tectonophysics 170: 89-114

61. Pirazzoli PA, Laborel J, Stiros SC (1996) Earthquake clustering in the eastern Mediterranean during historical times. Journal of Geophysical Research 101: 6083-6098

62. Remia A, Taviani M (2005) Shallow-buried Pleistocene Madrepora-coral mounds on a muddy continental slope, Tuscan Archipelago, NE Tyrrhenian Sea. Facies 50: 419-425

63. Rollion-Bard C, Blamart D, Cuif JP, Juillet-Leclerc A (2003) Microanalysis of C and O isotopes of azooxanthellate and zooxanthellate corals by ion microprobe. Coral Reefs 22: $405-415$

64. Sabelli B, Giannuzzi-Savelli R, Bedulli D (1990) Catalogo annotato dei molluschi marini del Mediterraneo. Vol. 1. Libreria Naturalistica Bolognese, Bolgona. pp. 348

65. Safriel U (1966) Recent vermetid formation on the Mediterranean shore of Israel. Proc. Malacol. Soc. London 37: 27-34

66. Safriel U (1974) Vermetid gastropods and intertidal reefs in Israel and Bermuda. Science 186: $1113-1115$

67. Schiaparelli S, Alberelli G, Cattaneo-Vietti R (2006) Phenotypic plasticity of Vermetidae suspension feeding: a potential bias in their use as Biological Sea-Level Indicators. Marine Ecology 27: 44-53

68. Schiller C (1993) Ecology of the symbiotic coral Cladocora caespitosa (L.) (Faviidae, Scleractinian) in the Bay of Piran (Adriatic Sea): I. Distribution and biometry. Marine Ecology 14: 205-219

69. Schneider T (2006) The general circulation of the atmosphere. Annual Review of Earth and Planetary Science 34: 655-688

70. Schröder-Ritzrau A, Mangini A, Lomitschka M (2003) Deep-sea corals evidence periodic reduced ventilation in the North Atlantic during the LGM/Holocene transition. Earth and Planetary Science Letters 216: 399-410

71. Silenzi S, Antonioli F, Chemello R (2004) A new marker for sea surface temperature trend during the last centuries in temperate areas: vermetid reef. Global and Planetary Change 40/1-2: 105-114

72. Silenzi S, Bard E, Montagna P, Antonioli F (2005) Isotopic and elemental records in a nontropical coral (Cladocora caespitosa): Discovery of a new high-resolution climate archive for the Mediterranean Sea. Global and Planetary Change 49: 94-120

73. Sinclair DJ, Kinsley LPJ, McCulloch MT (1998) High-resolution analysis of trace elements in corals by laser ablation ICP-MS. Geochimica et Cosmochimica Acta 62: 1889-1901

74. Sinclair DJ, Williams B, Risk M (2006) A biological origin for climate signals in corals - trace element "vital effects" are ubiquitous in scleractinian coral skeletons. Geophysical Research Letters 33, L17707, DOI:10.1029/2006GL027183

75. Smith SV, Buddemeier RV, Redalje RC, Houck JE (1979) Strontium-calcium thermometry in coral skeletons. Science 204: 404-407

76. Smith JE, Risk MJ, Schwarcz HP, McConnaughey TA (1997) Rapid climate change in the North Atlantic during the Younger Dryas recorded by deep-sea corals. Nature 386: 818-820

77. Smith JE, Schwarcz HP, Risk MJ, McConnaughey TA, Keller N (2000) Paleotemperatures from deep-sea corals: overcoming "vital effects". Palaios 15: 25-32

78. Somot S, Sevault F, Déqué M (2006) Transient climate change scenario simulation of the Mediterranean Sea for the twenty-first century using a high-resolution ocean circulation model, Climate Dynamics 27: 851-879

79. Stephenson TA, Stephenson A (1954) The Bermuda Islands. Endeavour 50: 72-80

80. Laborel J, Laborel-Deguen F, Papageorgiou S, Evin J, Pirazzoli PA, Stiros SC, (2000) Seismic coastal uplift in a region of subsidence: Holocene raised shorelines of Samos Island, Aegean Sea, Greece. Marine Geology 170: 41-58 
81. Taviani, M (2002) The Mediterranean benthos from Late Miocene up to Present: ten million years of dramatic climatic and geological vicissitudes. Biologia Marina Mediterranea 9: 445-463

82. Taviani M, Corselli C, Freiwald A, Malinverno E, Mastrototaro F, Remia A, Savini A, Tursi, A (2005a). First geo-marine survey of living cold-water Lophelia reefs in the Ionian Sea (Mediterranean basin). Facies 50: 409-417

83. Taviani M, Freiwald A, Zibrowius H (2005b) Deep-coral growth in the Mediterranean Sea: an overview. In: Freiwald A, Roberts M (eds.) Deep-water Corals and Ecosystems, Springer-Verlag: $137-156$

84. Triolo R, Gorgoni C, Lo Celso F, Baron M, Pallante P, Schwahn D, Kentzinger E, Riso A, Ruffo L (2003) Application of the USANS Technique in Natural Sciences and Archaeometry. Abstracts of Scientific Presentations of the first workshop of the International Consortium on Ultra-Small-Angle Scattering (IConUSAS), Oak Ridge pp. 27

85. Van Andel T, Laborel J (1964) Recent high relative sea level stand near Recife, Brazil. Science 145: 580-581

86. Weber JN, Woodhead PMJ (1972) Temperature dependence of oxygen-18 concentration in reef coral carbonates. Journal of Geophysical Research 77: 463-473

87. Wellington GM, Dunbar RB (1995) Stable isotopic signatures of El Niño-Southern Oscillation events in the eastern tropical Pacific reef corals. Coral Reefs 14: 5-25

88. Zibrowius H (1980) Les Scléractiniaires de la Méditerranée et de l'Atlantique nord-oriental. Mém. Inst. Océanogr. 11: 1-284 